
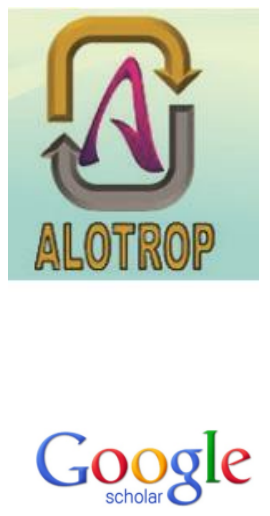

\section{PENERAPAN MODEL PEMBELAJARAN AUDITORY, INTELLECTUALY DAN REPETITION (AIR) DENGAN MENGGUNAKAN MEDIA PEMBELAJARAN KARTU ARISAN UNTUK MENINGKATKAN AKTIVITAS DAN HASIL BELAJAR SISWA KELAS X MIA 1 SMAN 8 KOTA BENGKULU} Diana Sumiati* ${ }^{1}$, Amrul Bahar ${ }^{2}$, Dewi Handayani ${ }^{3}$

1,2,3 Program Studi Pendidikan Kimia Jurusan PMIPA FKIP Universitas Bengkulu

*E-mail : dianasumiati1295@gmail.com

\title{
ABSTRACT
}

This study aimed to improve learning activities and learning outcomes of students in class X MIA 1 of Senior High School (SMAN) 8 Bengkulu on the subject of chemical bonds through the application of Auditory, Intellectualy, and Repetition (AIR) learning models by using learning media with lottery card. This study is a classroom action research consisting of three cycles, each cycle consisting of four stages, planning, action, observation and reflection. In collection of data was done by non-test and test methods, teacher observation sheets, student observation sheets and post-test. The data was processed by using simple quantitative data analysis techniques, the total value of each student, the average value, the percentage of absorptive power, learning completeness and the average observation score.The results of the study in the 2018/2019 school year showed that the application of the Auditory Intellectualy Repitition learning model using learning media with lottery cards in class X MIA 1 of SMA Negeri 8 Kota Bengkulu could improve teacher activities, student activities and student chemistry learning outcomes. This can be seen from the average score of teacher activities in the first cycle to the third cycle in a row : 23, 27.5 and 31.5. Student activity also showed improvement in each cycle. The average score of student activity in cycle I to cycle III was sequentially 20 , 25 29.5. Learning outcomes also increase in each cycle. This can be seen from the average value of the test results in each cycle, in the first cycle of 61.82, in the second cycle of 67.88, in the third cycle of 79.09. Classical absorption in cycle I, cycle II, cycle III are $61.82 \%, 67.88 \%, 79.09 \%$, with the percentage of completeness learning in each cycle of $42 \%, 73 \%$, and $87.8 \%$.

Keywords: Auditory Learning Model, Intellectualy, and Repetition (AIR), Arisan Cards, Activities, Learning Outcomes.

\section{ABSTRAK}

Penelitian ini bertujuan untuk meningkatkan aktivitas belajar dan hasil belajar siswa dikelas X MIA 1 SMA Negeri 8 Kota Bengkulu pada pokok bahasan ikatan kimia melalui penerapan model pembelajaran Auditory, Intellectualy, dan Repetition (AIR) dengan menggunakan media pembelajaran kartu arisan. Penelitian ini merupakan penelitian tindakan kelas yang terdiri dari tiga siklus, masing-masing siklus terdiri dari empat tahapan yaitu perencanaan, pelaksanaan tindakan, observasi dan refleksi. Pengumpulan data dilakukan dengan cara non tes dan tes yaitu lembar observasi guru, lembar observasi siswa dan post test. Data diolah dengn menggunkan teknik analisis data kuantitatif sederhana yaitu nilai total setiap siswa, nilai rata-rata, persentase daya serap, ketuntasan belajar dan rata-rata skor observasi. Hasil penelitian pada semester ganjil tahun ajaran 2018/2019menunjukan penerapan model pembelajaran Auditory Intellectualy Repitition dengan menggunakan media kartu arisandikelas X MIA 1 SMA Negeri 8 Kota Bengkulu dapat meningkatkan aktivitas guru, aktivitas siswa dan hasil belajar kimia siswa. Hal ini dapat dilihat dari skor rata-rata aktivitas guru pada siklus I sampai siklus III secara berurutan yaitu 23, 27,5 dan 31,5. Aktivitas siswa juga menunjukan peningkatan pada setiap siklus. Skor rata-rata aktivitas siswa pada siklus I sampai siklus III secara berurutan yaitu 20, 25 29,5. Hasil belajar juga terdapat peningkatan pada setiap siklus. Hal ini dapat lihat dai nilai rata-rata hasil tes pada masingmasing siklus yaitu pada siklus I sebesar 61,818, pada siklus II sebesar 67,88, pada siklus III sebesar 79,09. Daya serap klasikal pada siklus I, siklus II, siklus III secara berturut-turut adalah $61,82 \%, 67,88 \%, 79,09 \%$, dengan persentase ketuntasan belajar klasikal setiap siklusnya sebesar $42 \%$, $73 \%$, dan $87,8 \%$.

Kata Kunci : Model Pembelajaran Auditory, Intellectualy, dan Repetition (AIR), Kartu Arisan, Aktivitas, Hasil Belajar.

\section{PENDAHULUAN}

Dalam era globalisasi, kimia merupakan ilmu pengetahuan yang memiliki peran penting dalam meningkatkan kualitas sumber daya manusia khususnya dibidang pendidikan [1]. Setiap pembelajaran kimia harus berkesinambungan, sehingga mempelajarinya harus bertahap dan terstruktur yaitu dimulai dari tingkat yang sederhana ke tingkat yang lebih kompleks yang bertujuan agar siswa terbiasa berpikir logis, sistematis dan kritis serta mampu bekerjasama dengan baik dalam proses belajar mengajar [2]

Belajar merupakan proses perubahan tingkah laku yang dilakukan secara sengaja untuk mendapatkan perubahan yang lebih baik yang akan timbul dengan adanya pengalaman dan latihan [3]. Suatu proses pembelajaran dapat dikatakan berhasil apabila dalam proses pembelajaran, peserta didik mampu mengalami perubahan, baik perubahan 
dalam pengetahuan, kemampuan, nilai, sikap atau sifat pribadi lainnya [4]. Untuk mencapai hasil pembelajaran yang maksimal, maka dalam pembelajaran kimia guru hendaklah menggunakan model pembelajaran yang sesuai, sehingga dapat melibatkan siswa untuk turut aktif dalam proses pembelajaran dan siswa dapat mengaplikasikan pelajaran tersebut [5].

Berdasarkan hasil observasi yang dilakukan di SMAN 8 Kota Bengkulu, saat pembelajaran kimia berlangsung guru masih menggunakan metode konvensional yang hanya berpusat pada guru. Sebagian besar siswa tidak mendengarkan penjelasan guru dan sibuk dengan aktivitas masingmasing sehingga proses pembelajaran menjadi kurang aktif dan membosankan .

Hasil observasi menunjukkan bahwa nilai ulangan harian siswa mata pelajaran kimia belum mencapai nilai Kriteria Ketuntasan Minimal (KKM) yaitu $\geq 70$ yakni hanya sebesar 60,8 . Rendahnya nilai belajar diduga disebabkan oleh beberapa faktor antara lain kurangnya minat belajar siswa, guru mengajar cenderung monoton, serta model pembelajaran yang merupakan faktor yang paling dominan mempengaruhi hasil belajar [6].

Model pembelajaran adalah skenario dalam proses belajar mengajar [7], karena itu seharusnya bisa menciptakan suasana belajar yang efektif serta dapat meningkatkan aktivitas dan hasil belajar [8]. Saat ini, ada banyak sekali model pembelajaran yang dikembangkan agar pembelajaran lebih efektif dan tidak semata-mata terpusat pada guru salah satunya model pembelajaran tipe kooperatif [9]. Model pembelajaran kooperatif adalah suatu model pembelajaran dimana siswa belajar dan bekerja dalam kelompok-kelompok kecil secara kolaboratif yang anggotanya 4-6 orang dengan struktur kelompok heterogen [10]. Pada penelitian ini, peneliti menggunakan model pembelajaran tipe kooperatif yaitu model pembelajaran Auditory, Intellectually, And Repetition (AIR). Model pembelajaran AIR merupakan suatu model pembelajaran yang efektif dengan memperhatikan tiga hal, yaitu Auditory, Intellectualy, dan Repetition", yang mana menuntut siswa untuk lebih aktif, sedangkan guru yang mengajar sebagai fasilitator siswa dalam belajar [11].

Penggunaan model pembelajaran AIR lebih memberikan kesempatan siswa dalam bekerja sama dengan teman-teman kelompoknya untuk memahami konsep pelajaran yang diberikan oleh guru agar tercapai tujuan pembelajaran [12]. Selain itu untuk menunjang model pembelajaran agar prosesnya terjalan dengan maksimal sehingga dapat mencapai tujuan pelajaran dengan baik, maka diperlukan juga suatu media pembelajaran pendukung[13].

Media pembelajaran merupakan suatu alat bantu guru dalam mengajar serta sarana pembawa pesan dari sumber belajar ke penerima pesan belajar sehingga memudahkan siswa dalam memahami materi yang disampaikan oleh guru [14]. Media adalah segala sesuatu yang dapat digunakan untuk menyalurkan pesan dari pengirim ke penerima sehingga dapat merangsang pikiran, perasaan, perhatian dan minat siswa sedemikian rupa sehingga terjadi proses belajar [15]. Dewasa ini banyak sekali media pembelajaran yang yang bisa digunakan, salah satunya adalah media kartu arisan [16].

Media kartu arisan adalah alat bantu pengajaran yang berupa karyu kertas berukuran $10 \mathrm{X}$ $10 \mathrm{~cm}$ yang di persiapkan oleh guru sebanyak jumlah siswa di dalam kelas. Isi dari kartu ini di bedakan menjadi dua yaitu sebagian kartu berisi soal-soal tentang materi yang diajarkan dan sebagian lagi berisi jawaban dari soal-soal tersebut. Dengan demikian, peneliti beranggapan bahwa penggunaan model pembelajaran AIR dengan disertai media pembelajaran kartu arisan dapat memudahkan siswa memahami materi yang diajarkan oleh guru.

Pembelajaran yang dilakukan dengan model pembelajaran AIR dengan bantuan media kartu arisan diharapkan dapat membantu siswa untuk terlibat aktif dalam proses pembelajaran serta membantu siswa untuk melatih keberanian mereka dalam mengeluarkan pendapat. Dengan demikian guru dapat mengetahui kesulitan siswa saat proses pembelajaran, serta dapat mengatasi kesulitan dengan didiskusikan bersama-sama dengan melibatkan siswa. Berdasarkan latar belakang, maka peneliti melakukan penelitian yang berjudul "Penerapan Model Pembelajaran Auditory, Intellectualy, dan Repetition (AIR) dengan Menggunakan Media Kartu ArisanUntuk Meningkatkan Aktivitas Dan Hasil Belajar Siswa Kelas X MIA 1 SMAN 8 Kota Bengkulu".

\section{METODE PENELITIAN}

Penelitian ini merupakan Jenis penelitian tindakan kelas (Classroom Action Research). Penelitian tindakan kelas merupakan kegiatan ilmiah yang dilakukan guru di kelas dengan jalan merancang, melaksanakan, mengamati, serta merefleksikan suatu tindakan melalui siklus-siklus secara kolaboratif dan partisipatif yang bertujuan untuk memperbaiki atau meningkatkan proses belajar mengajar dikelas [17]. Penelitian di lakukan di Kelas X MIA1 SMAN 08 Kota Bengkulu pada bulan September hingga bulan oktober tahun ajaran 2018/2019. Objek penelitian ini adalah siswa kelas $\mathrm{X}$ MIA 1 yang berjumlah 33 orang yang terdiri dari 
12 orang siswa laki-laki dan 21 orang siswa perempuan. Instrumen penelitian yang digunakan adalah Lembar tes dan lembar observasi. Teknik analisa data yang digunakan adalah analisa data tes dan analisa data observasi.

Pada penelitian ini dilakukan penerapan model pembelajaran auditory, Intellectually and repetition (AIR) yang bertujuan membuat siswa lebih aktif dalam belajar, termotivasi untuk memberikan pembuktian dan penjelasan yang mereka dapat. Selain itu juga, dengan repetition (pengulangan) membuat pelajaran yang diberikan akan lebih lama membekas dalam ingatan siswa dibandingkan dengan pembelajaran yang tidak memiliki tahapan repetition (pengulangan) $[18\}$. Pada model pembelajaran ini, ketiga komponen pembelajaran AIR dalam penerapannya saling berkaitan.

Agar proses pembelajaran lebih menarik, peneliti menggabungkan model pembelajaran AIR dengan media kartu arisan yang dimodifikasi dari model pembelajaran kartu arisan. Pada penelitian ini kartu arisan dibagi menjadi dua yaitu kertas soal dan kartu jawaban. Untuk jawaban ditulis dalam kartu, sedangkan pertanyaan ditulis di kertas kemudian digulung. Gulungan kertas pertanyaan dimasukan kedalam gelas untuk diundi. Setelah dilakukan pengundian soal, guru membacakan gulungan soal yang terpilih, sedangkan siswa menyimak dan mencocokan jawaban yang dibacakan oleh guru. Jika jawaban yang ada pada siswa sesuai dengan pertanyaan yang dibacakan oleh guru maka kelompok tersebut akan mempresentasikan jawaban tersebut di depan kelas

Pada awal pembelajaran, sebelum siswa berdiskusi guru menjelaskan materi yang akan dibahas terlebih dahulu dimana dalam model pembelajaran ini siswa secara berkelompok dituntut untuk mendengarkan dan menyimak (Auditory), sekaligus berfikir tentang materi yang disampaikan oleh guru (auditory and intellectually), Sehingga secara tidak langsung siswa merespons apa yang disampaikan oleh guru (Auditory). Sebagian siswa merespon penjelasan dari guru dengan cara bertanya atau memberikan penekanan pada materi yang mereka pahami.

Setelah memberikan penjelasan, guru mengarahkan siswa untuk berdiskusi dengan menggunakan media kartu arisan dimana sebelumnya guru membagikan jawaban dari soal yang akan diacak, lalu guru membacakan soal tersebut. Siswa mendengarkan dan mencocokkan untuk memecahkan masalah pada kartu jawaban (Intellectually). Kegiatan pembelajaran diakhiri berupa kegiatan siswa mempresentasikan hasil diskusi mereka didepan kelas.
Untuk melihat aktivitas siswa dan guru pada proses kegiatan belajar mengajar di amati oleh dua orang observer. Observer tersebut mengamati dan melakukan penilaian secara objektif sesuai dengan lembar observasi yang disediakan. Observasi dilaksanakan setiap siklus pertemuannya.

Pada setiap siklus yang dilakukan, guru selalu melakukan refleksi perbaikan dan kekurangan yang terjadi pada siklus sebelumnya sehingga diperoleh hasil yang lebih baik.

\section{HASIL DAN PEMBAHASAN}

Hasil penelitian meliputi hasil belajar siswa, hasil observasi aktivitas guru dan hasil observasi aktivitas siswa dari siklus I, II dan III sampai dengan tahap tindakan yang diuraikan sebagai berikut.

\section{Refleksi Awal}

Penelitian ini dilaksanakan pada tanggal 15 29 Oktober 2018 tahun ajaran 2018/2019 dikelas X MIA 1 SMA N 8 Bengkulu dengan jumlah siswa 33 orang Sebelum melakukan tindakan, peneliti melakukan refleksi awal. Refleksi awal bertujuan untuk mengetahui kendala-kendala yang sering terjadi pada saat proses pembelajaran kimia yang berlangsung di kelas . Refleksi awal yang peneliti lakukan adalah wawancara terhadap guru tentang bagaimana proses belajar mengajar kimia yang dilakukan guru terutama mengenai strategi yang dilakukan guru saat mengajar dan keaktifan siswa saat kegiatan belajar mengajar khusus bidang studi kimia. Berdasarkan hasil wawancara tersebut ternyata hasil yang diperoleh siswa masih banyak kekurangan.

\section{Siklus l}

Siklus 1 dilaksanakan pada tanggal 15 oktober 2018 dengan alokasi waktu 3 x 45 menit. Materi yang diajarkan adalah bab ikatan kimia dengan sub $\mathrm{Bab}$ materi kestabilan unsur,struktur Lewis, dan Ikatan ion.

\section{Hasil Observasi aktivitas guru dan siswa}

Observasi terhadap guru dilakukan oleh dua orang pengamat. Hasil analisis data observasi yang dilakukan merupakan gambaran aktivitas guru dan siswa selama proses pembelajaran pada siklus 1 .

Hasil analisis data observasi yang dilakukan dapat dilihat pada tabel 1

Berdasarkan Hasil observasi tersebut diatas, rata-rata skor aktivitas guru yang diperoleh adalah 23 sehingga secara keseluruhan aktivitas guru dalam proses pembelajaraan pada siklus ini termasuk dalam kriteria cukup. Untuk hasil analisis observasi aktivitas siswa, rata-rata skor yang diperoleh adalah 20 sehingga secara keseluruhan aktivitas siswa 
dalam proses pembelajaraan pada siklus ini termasuk dalam kriteria cukup.

\section{Tabel .1 Data Hasil Observasi Aktivitas Guru Dan Siswa Siklus 1}

\begin{tabular}{|c|c|c|c|c|}
\hline \multirow[t]{2}{*}{ Siklus } & \multicolumn{2}{|c|}{ Skor Observasi } & \multirow{2}{*}{$\begin{array}{l}\text { Rata- } \\
\text { Rata } \\
\text { Skor }\end{array}$} & \multirow[t]{3}{*}{ Kriteria } \\
\hline & Pengamat & Pengamat & & \\
\hline & \multicolumn{3}{|c|}{ Aktivitas Guru } & \\
\hline \multirow[t]{3}{*}{1} & 22 & 24 & 23 & Cukup \\
\hline & \multicolumn{4}{|c|}{ Aktivitas Siswa } \\
\hline & 18 & 22 & 20 & Cukup \\
\hline
\end{tabular}

\section{Hasil Belajar Siswa}

Berhasil atau tidaknya suatu proses pembelajaran dapat dilihat dari peningkatan hasil belajar siswa. Pada penelitian ini didapatkan hasil belajar siswa pada siklus 1 seperti yang tercantum pada tabel 2

\section{Tabel 2. Data hasil belajar Siswa siklus 1}

\begin{tabular}{lc}
\hline Data yang dianalisis & Hasil Analisis \\
\cline { 2 - 2 } & Siklus 1 \\
Jumlah siswa secara keseluruhan & 33 \\
Jumlah Siswa yang mengikuti test & 33 \\
Jumlah Siswa yang tuntas & 14 \\
Jumlah Siswa yang tidak tuntas & 19 \\
Nilai Tertinggi & 80 \\
Nilai Terendah & 30 \\
Nilai rata-rata siswa & 61,818 \\
Daya Serap Klasikal & $61,82 \%$ \\
Ketuntasan belajar klasikal & $42 \%$ \\
Kesimpulan & Belum Tuntas \\
\hline
\end{tabular}

Berdasarkan tabel 2 hasil yang diperoleh dari post test siswa pada siklus 1 dapat dilihat masih banyak nilai rata-rata siswa yang belum tuntas atau belum memenuhi kriteria, sehingga perlu dilakukan tindakan lanjutan.

\section{Refleksi Siklus 1}

Berdasarkan Hasil pembelajaran yang telah dilakukan pada siklus 1 terdapat beberapa kekurangan. Sehingga perlu dilakukan perbaikan perbaikan untuk siklus selanjutnya.

Berikut kekurangan-kekurangan yang dilakukan pada siklus 1 :
1. Guru belum optimal dalam memberikan motivasi dan memusatkan perhatian siswa dalam tujuan pembelajaran yang akan diberikan.

2. Guru belum optimal dalam membimbing siswa dalam pelaksanaan model pembelajaran Auditory, Intellectually, and Repetition ( AIR )

3. Guru belum optimal dalam memberikan kesempatan siswa untuk mempersentasikan dan mengkomunikasikan jawabannya di depan kelas.

\section{Siklus ll}

Siklus 11 dilaksanakan pada tanggal 22 oktober 2018 dengan alokasi waktu 3 x 45 menit. Materi yang diajarkan adalah Bab Ikatan kimia dengan sub bab materi Pengertian ikatan kovalen dan Mekanisme pembentukan ikatan kovalen.

\section{Hasil Observasi Aktivitas Guru Dan Siswa}

Dalam pelaksanaan tindakan untuk siklus II, guru melakukan perbaikan-perbaikan terhadap kekurangan yang terdapat pada siklus I . dari hasil observasi terhadap aktivitas guru dan siswa yang diamati oleh dua orang pengamat, maka diperoleh skor data observasi seperti pada tabel 3

\section{Tabel 3 Data hasil observasi aktivitas guru Dan Siswa siklus ll}

\begin{tabular}{ccccc}
\hline Siklus & \multicolumn{2}{c}{ Skor Observasi } & Rata- & Kriteria \\
\cline { 2 - 3 } & Pengamat & Pengamat & Rata & \\
& 1 & 2 & Skor & \\
& & \multicolumn{4}{c}{ Aktivitas Guru } \\
2 & 26 & 29 & 27,5 & Baik \\
& \multicolumn{4}{c}{ Aktivitas Siswa } \\
& 24 & 26 & 25 & Cukup \\
\hline
\end{tabular}

Berdasarkan Hasil observasi diatas, rata-rata skor aktivitas guru yang diperoleh adalah 27,5 sehingga secara keseluruhan aktivitas guru dalam proses pembelajaraan pada siklus ini telah mencapai kriteria baik. Untuk hasil analisis observasi aktivitas siswa, rata-rata skor yang diperoleh adalah 25 sehingga aktivitas siswa dalam proses pembelajaraan pada siklus ini termasuk dalam kriteria cukup

\section{Hasil Belajar Siswa}

Dari hasil analisis Postest yang dikerjakan oleh siswa, diperoleh data hasil belajar siswa pada tabel 4.

Berdasarkan tabel 4 hasil yang diperoleh dari post test siswa pada siklus II dapat dilihat masih banyak nilai rata-rata siswa yang belum tuntas atau belum memenuhi kriteria, sehingga perlu dilakukan tindakan lanjutan. 
Tabel .4 Data Hasil Belajar Siswa Siklus Il

\begin{tabular}{lc}
\hline \multicolumn{1}{c}{ Data yang dianalisis } & Hasil Analisis \\
\cline { 2 - 2 } & Siklus ll \\
Jumlah siswa secara keseluruhan & 33 \\
Jumlah Siswa yang mengikuti test & 33 \\
Jumlah Siswa yang tuntas & 24 \\
Jumlah Siswa yang tidak tuntas & 9 \\
Nilai Tertinggi & 90 \\
Nilai Terendah & 40 \\
Nilai rata-rata siswa & 67,88 \\
Daya Serap Klasikal & $67,88 \%$ \\
Ketuntasan belajar klasikal & $73 \%$ \\
Kesimpulan & Belum Tuntas \\
\hline
\end{tabular}

\section{Refleksi Siklus ll}

Berdasarkan hasil pembelajaran dari siklus 11 , masih ada beberapa kekurangan sehingga perlu dilakukan perbaikan pada siklus selanjutnya. Adapun kekurangan - kekurangan yang terdapat pada siklus 11 adalah sebagai berikut :

1. Masih ada sebagian siswa yang belum bisa tertib dalam membentuk kelompok saat akan berdiskusi

2. Saat mengerjakan postest masih ada beberapa siswa yang tidak tertib

\section{Siklus Ill}

Siklus 3 dilaksanakan pada hari Senin, 29 Oktober 2018 dengan Alokasi waktu 3 x 45 menit. Materi yang diajarkan adalah sub bab jenis-jenis ikatan kovalen. Pelaksanaan siklus 111 ini dilakukan dengan mengacu pada hasil refleksi siklus 11 .

\section{Hasil Observasi Aktivitas Guru dan Siswa}

Hasil Observasi Aktivitas guru dan siswa yang dilakukan oleh dua pengamat pada siklus 111 dapat dilihat pada tabel 5 :

\section{Tabel 5. Hasil Observasi Guru Dan Siswa Siklus Ill}

\begin{tabular}{ccccc}
\hline Siklus & \multicolumn{2}{c}{ Skor Observasi } & Rata- & Kriteria \\
\cline { 2 - 3 } & Pengamat & Pengamat & Rata \\
& 1 & 2 & Skor & \\
& \multirow{4}{*}{3} & \multicolumn{2}{c}{ Aktivitas Guru } \\
& 31 & 32 & 31,5 & Baik \\
& \multicolumn{4}{c}{ Aktivitas Siswa } \\
& 29 & 30 & 29,5 & Baik \\
\hline
\end{tabular}

Berdasarkan Hasil observasi diatas, rata-rata skor aktivitas guru yang diperoleh adalah 31,5 sehingga secara keseluruhan aktivitas guru dalam proses pembelajaraan pada siklus ini telah mencapai kriteria baik. Untuk hasil analisis observasi aktivitas siswa, rata-rata skor yang diperoleh adalah 29,5 sehingga aktivitas siswa dalam proses pembelajaraan pada siklus ini termasuk dalam kriteria baik.

\section{Hasil Belajar Siswa}

Keberhasilan dapat dicapai jika sesuai dengan tujuan pembelajaran, dan hal ini tidak terlepas dari hasil belajar siswa. Berdasarkan hasil postest siswa pada siklus 11l, maka dapat disimpulkan data hasil belajar siswa sebagai pada tabel 6 .

\section{Tabel 6. Data Hasil Belajar Siswa Siklus Ill}

\begin{tabular}{lc}
\hline \multicolumn{1}{c}{ Data yang dianalisis } & Hasil Analisis \\
\cline { 2 - 2 } & Siklus lll \\
Jumlah siswa secara keseluruhan & 33 \\
Jumlah Siswa yang mengikuti test & 33 \\
Jumlah Siswa yang tuntas & 29 \\
Jumlah Siswa yang tidak tuntas & 4 \\
Nilai Tertinggi & 100 \\
Nilai Terendah & 50 \\
Nilai rata-rata siswa & 79,09 \\
Daya Serap Klasikal & $79,09 \%$ \\
Ketuntasan belajar klasikal & $87,8 \%$ \\
Kesimpulan & Tuntas \\
\hline
\end{tabular}

Berdasarkan tabel 6 hasil yang diperoleh dari post test siswa pada siklus III dapat dilihat nilai rata-rata siswa seluruhnya telah mencapai tuntas dan telah memenuhi kriteria, sehingga tidak perlu dilakukan tindakan lanjutan.

\section{Refleksi Siklus Ill}

Pada Siklus 111 nilai rata-rata siswa meningkat melampaui batas minimal ketuntasan yang ditentukan oleh sekolah.

Hal-hal yang telah tercapai pada siklus lll yaitu :

1. Secara keseluruhan, aktivitas guru dan aktivitas siswa sudah bisa digolongkan dalam kategori baik

2. Siswa mulai memiliki kesadaran untuk selalu tertib pada proses pembelajaran

3. Siswa mengerjakan postest dengan baik terlihat dari hasil postest yang didapat pada siklus 111

\section{PEMBAHASAN}

Aktivitas belajar dapat didefinisikan sebagai aktivitas yang diberikan pada pembelajaran dalam situasi belajar mengajar [19]. Pengajaran yang efektif adalah pengajaran yang menyedikan kesempatan belajar sendiri atau melakukan hal sendiri [20]. Dalam hal ini, siswa lebih dituntut untuk lebih aktif dalam proses belajar mengajar. Sedangkan guru merupakan fasilitator yang bertugas 
mengarahkan dan membimbing siswa saat proses belajar mengajar berlangsung. Keberhasilan dalam proses pembelajaran sangat berkaitan erat dengan aktivitas guru dan aktivitas siswa [21] Pada penelitian ini aktivitas didalam proses pembelajaran diukur pada setiap siklusnya dengan lembar observasi .

Kelebihan pembelajaran dengan menggunakan model AIR dapat mengakibatkan siswa memiliki kemampuan yang lebih dalam pemahaman, kreativitas, dan keaktifan dalam pembelajaran, kemampuan memecahkan masalah dan daya ingat yang kuat [22].

Berdasarkan hasil analisa data yang telah dilakukan, setiap siklus memiliki hasil aktivitas yang berbeda-beda serta mengalami peningkatan hasil pada setiap siklusnya. Besarnya maing -masing perubahan berupa peningkatan rata-rata aktivitas guru ( Gambar 1) dan Siswa (Gambar 2) dari siklus 1 hingga siklus lll dapat dilihat dibawah ini:

\section{Rata-rata skor aktivitas guru}



Gambar 1 Grafik Rata-rata Skor Aktivitas Guru



\section{Gambar 2. Grafik rata-rata skor aktivitas Siswa}

Dari grafik 1 dan grafik 2 dapat dilihat bahwa aktivitas guru dan siswa terus mengalami peningkatan dari siklus 1 hingga siklus 111 yang berarti aktivitas siswa dan guru terus membaik dari sebelumnya. Berdasarkan perhitungan yang telah dilakukan, maka kisaran skor penilaian untuk lembar observasi aktivitas belajar siswa dapat dikategorikan baik apabila didapatkan skor nilai berada pada rentang 25,54 $<x \leq 33$, sehingga jika diamati dari grafik 1 hasil observasi aktivitas guru dengan kategori baik dicapai mulai dari siklus 11 sedangkan untuk hasil observasi aktivitas siswa dengan kategori baik dicapai pada siklus 111 .

Pada siklus 1, guru belum optimal memberikan motivasi dan memusatkan perhatian pada siswa. Sehingga, ketika dalam proses belajar mengajar interaksi antara guru dan siswa belum terjalin dengan baik. Seperti model pembelajaran lainnya, model pembelajaran AIR juga memiliki kelemahan [23]. Salah satu kelemahan model pembelajaran ini adalah guru harus memberikan masalah yang bermakna dan mudah dipahami oleh siswa sehingga pada tahap ini siswa seharusnya memiliki motivasi yang kuat agar mereka tidak merasa bosan dalam pembelajaran.

Pada saat pelaksanaan siklus 1 Siswa masih belum memahami model pembelajaran yang digunakan, hal ini dapat dilihat saat proses pembelajaran berlangsung beberapa siswa masih bertanya mengenai hal-hal yang harus dilakukan selanjutnya. Pada saat pembagian kelompok diskusi, beberapa siswa masih kurang tertib.

Pada Siklus 11 guru melakukan perbaikan dari hasil refleksi sebelumnya, Guru melakukan pembagian kelompok diskusi siswa pada awal pembelajaran. Namun, beberapa siswa masih kurang tertib hal ini dikarenakan faktor guru yang belum terlalu tegas dengan siswa. Berdasarkan hasil observasi dari dua orang observer, setelah data dianalisis didapatkan skor rata-rata aktivitas siswa sebesar 25. Skor rata-rata tersebut belum dikategorikan baik, namun sudah mengalami peningkatan jika dibandingkan dengan siklus sebelumnya.

Pada siklus 1ll, Guru kembali melakukan perbaikan-perbaikan berdasarkan hasil refleksi siklus 1 dan siklus 1l. Pada siklus 111 ini, siswa sudah terbiasa dengan model pembelajaran yang diterapkan sehingga siswa lebih mudah diarahkan. Jika dilihat dari grafik pada gambar 1 diatas, pada siklus 111 ini aktivitas siswa sudah dikategorikan baik dengan nilai skor aktivitas rata-rata sebesar 29,5. sehingga disimpulkan bahwa penerapan model pembelajaran AIR dengan menggunakan media pembelajaran kartu arisan dapat meningkatkan Aktivitas belajar siswa. Hal ini sesuai dengan hasil penelitian Nurmansyah (2018) yang mengatakan bahwa penerapan model pembelajaran AIR dapat meningkatkan aktivitas belajar siswa [24].

Pada penelitian ini, penerapan model pembelajaran AIR dengan menggunakan media pembelajaran kartu arisan juga bertujuan untuk 
meningkatkan hasil belajar siswa. Peningkatan hasil belajar siswa diukur dari hasil postest yang dikerjakan siswa pada akhir pertemuan. Berikut ini gambar grafik nilai rata-rata hasil belajar siswa serta grafik ketuntasan belajar klasikal untuk setiap siklusnya :

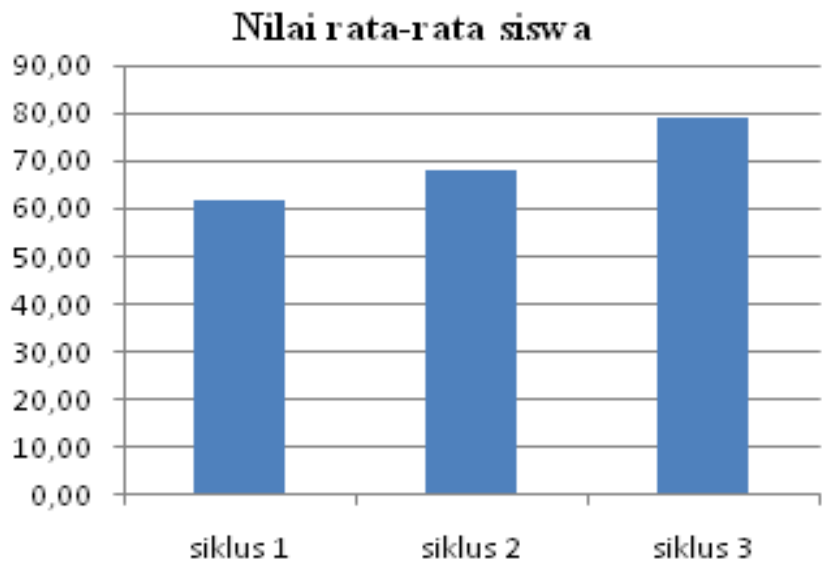

\section{Gambar 3 Perbandingan Nilai Rata-rata siswa}



\section{Gambar 4 Perbandingan Ketuntasan Belajar Klasikal untuk setiap siklus}

Berdasarkan grafik pada gambar 3 dan 4 nilai rata - rata siswa mengalami peningkatan dari siklus 1 ke siklus 11l. Nilai rata-rata siswa pada siklus 1 adalah 61,81 dengan nilai ketuntasan belajar klasikal sebesar $42 \%$. Nilai ketuntasan belajar yang didapatkan tersebut masih sangat jauh dengan nilai yang diharapkan. Aktivitas siswa pada siklus ini masih banyak kekurangan. Sehingga hal ini berdampak pada nilai yang diperoleh siswa. Keaktifan siswa selama proses belajar merupakan salah satu indikator adanya keinginan siswa untuk belajar [25].

Pada siklus 11 ini didapatkan hasil nilai rata-rata siswa adalah 67,88 serta ketuntasan belajar klasikal sebesar $73 \%$. Apabila dibandingkan dengan hasil dari siklus 1, maka pada siklus 11 ini nilai yang diperoleh mulai mengalami peningkatan. Hanya saja , jika dilihat dari hasil pencapaian nilai yang didapatkan tersebut masih belum memenuhi kriteria tuntas. Pada siklus 11 ini siswa belum terlalu bersungguh-sungguh dalam mengerjakan postest sehingga hasil yang didapatkanpun belum maksimal, beberapa siswa belum terlalu percaya diri dengan jawaban sendiri .

Pada siklus 11l, siswa telah memiliki kesadaran untuk mengerjakan postest dengan sungguhsungguh. Nilai rata-rata yang didapatkan adalah 79, 09 dengan ketuntasan pembelajaran sebesar 87,87 $\%$. Adapun siswa mencapai nilai tuntas pada siklus ini sebanyak 29 siswa sedangkan 4 siswa lainnya belum mencapai nilai tuntas. sehingga bisa disimpulkan bahwa pada siklus 111 ini hasil yang didapatkan dikategorikan dalam kriteria baik.

Dari penelitian yang dilakukan, keberhasilan pembelajaran terlihat pada siklus 111 dimana ketuntasan belajar sudah tercapai melebihi batas minimal dan daya serap klasikal juga mengalami peningkatan.

Secara keseluruhan model pembelajaran Auditory, Intellectually, And Repetition (AIR) dengan menggunakan media pembelajaran kartu arisan terbukti mampu membuat siswa untuk lebih aktif, sedangkan guru yang mengajar berperan sebagai fasilitator siswa dalam proses pembelajaran sehingga kesempatan siswa dalam bekerja sama dengan teman-teman kelompoknya akan lebih besar.

Dengan demikian, dapat disimpulkan bahwa pada penelitian ini penerapan model pembelajaran Auditory, Intellectually, And Repetition (AIR) dengan menggunakan media pembelajaran kartu arisan dapat meningkatkan aktivitas dan hasil belajar siswa pada materi ikatan kimia.

\section{KESIMPULAN}

Berdasarkan hasil penelitian yang dilakukan maka diperoleh kesimpulan sebagai berikut :

1. Penerapan model pembelajaran Auditory Intellectualy Repitition dengan menggunakan media kartu arisandikelas X MIA 1 SMAN 8 Kota Bengkulu dapat meningkatkan aktivitas belajar kimia siswa. Pada siklus I skor yang didapatkan adalah 20, pada siklus II sebesar 25 dan pada siklus III sebesar 29,5.

2. Penerapan model pembelajaran Auditory Intellectualy Repitition dengan menggunakan media kartu arisandikelas X MIA 1 SMAN 8 Kota Bengkulu dapat meningkatkan aktivitas guru dengan skor yang diperoleh pada siklus I adalah 23, pada siklus II diperoleh skor 27,5 dan pada siklus III diperoleh skor 31,5.

3. Penerapan model pembelajaran Auditory Intellectualy Repitition dengan menggunakan media kartu arisandikelas X MIA 1 SMAN 8 Kota Bengkulu dapat meningkatkan hasil belajar kimia siswa. Hal ini dapat lihat dai nilai rata-rata hasil tes pada masing-masing siklus yaitu pada 
siklus I sebesar 61,818, pada siklus II sebesar 67,88, pada siklus III sebesar 79,09. Daya serap klasikal pada siklus I, siklus II, siklus III secara berturut-turut adalah $61,82 \%, 67,88 \%, 79,09 \%$, dengan presentase ketuntasan belajar klasikal setiap siklusnya sebesar $42 \%, 73 \%$, dan $87,8 \%$.

\section{SARAN}

Berdasarkan hasil penelitian yang telah diperoleh, maka peneliti dapat memberikan saran :

1. Model pembelajaran Auditory Intellectualy Repitition dengan menggunakan media kartu arisan dapat dijadikan referensi dalam mengajar sehingga pembelajaran kimia menjadi lebih menyenangkan dan dapat membantu meningkatkan hasil belajar siswa.

2. Dalam menerapkan model pembelajaran Auditory Intellectualy Repitition dengan menggunakan media kartu arisan ini manajemen waktu harus sangat diperhatikan sehingga tujuan belajar dapat tercapai dengan maksimal.

\section{DAFTAR PUSTAKA}

[1] Laksono, P.J., Studi Kemampuan Literasi Kimia Mahasiswa Pendidikan Kimia Pada Materi Pengelolaan Limbah, Orbital: Jurnal Pendidikan Kimia , 2018: 2(1): 1-12.

[2] Yunita, A., Salastri Rohiat, Hermansyah Amir , Analisis Kemampuan Berpikir Kritis Mata Pelajaran Kimia Pada Siswa Kelas XI IPA SMAN 1 Kepahiang, Alotrop, 2018: 2(1): 33-38.

[3] Hanafy, M.S., Konsep Belajar Dan Pembelajaran, Lentera Pendidikan, 2014: 17(1): 66-79.

[4] Amir,H., Korelasi Pengaruh Faktor Efikasi Diri Dan Manajemen Diri Terhadap Motivasi Berprestasi Pada Mahasiswa Pendidikan Kimia Universitas Bengkulu, Manajer Pendidikan, 2016: 10(4): 336-342.

[5] Lestari, I.A, Hermansyah Amir, Salastri RohiatHubungan Persepsi Siswa Kelas X MIPA Di SMA Negeri Sekota Bengkulu Tahun Ajaran 2016/2017 Tentang Variasi Gaya Mengajar Guru Dengan Hasil Belajar Kimia, Alotrop, 2017:1(2): 113-116.

[6] Kurniawan, B., Ono Wiharna, Tatang Permana, Studi Analisis Faktor-faktor Yang Mempengaruhi Hasil Belajar Pada Mata Pelajaran Teknik Listrik Dasar Otomotif, Journal of Mechanical Engineering Education, 2017: 4 (2): 156162.

[7] Sidik NH, M.I., Hendri Winata, Meningkatkan hasil belajar siswa melalui penerapan model pembelajaran direct instruction, Jurnal Pendidikan Manajemen Perkantoran, 2016: 1(1): 49-60

[8] Ginting, S.M., Hermansyah Amir., Penerapan Model Pembelajaran Somatis, Auditori, Visual danIntelektual (SAVI) Berbantuan Media Komputer Untuk Meningkatkan Kualitas Pembelajaran Kimia Fisik II, Exacta,2012:10(1): 98-105

[9] Wiwit., Hermansyah.Amir, Dody Dori Putra, Penerapan Model Pembelajaran Kooperatif Tipe TGT dengan dan Tanpa Media Penggunaan Media Animasi Terhadap Hasil Belajar Kimia Siswa SMA Negeri 9 Kota Bengkulu. Exacta, 2012: 10 (1) : 71-78

[10] Sari, Y.A, Amrul Bahar, Salastri Rohiat., Studi Perbandingan Pembelajaran Kooperatif Menggunakan Media Kartu Pintar Dan Kartu KemudiPintar, Alotrop .2017: 1(1): 44-48

[11] Anwar, K., Marudin, Penerapan Model Pembelajaran Auditory, Intellectualy, Repetition (AIR) untuk Meningkatkan Hasil Belajar Siswa Kelas IV pada Mata Pelajaran PKn di SDN 11 Mataram, êl-Midad Jurnal Jurusan PGMI , 2018: 10 (1): 26-40

[12] Elinawati, W., Hilarius Jago Duda, Hendrikus Julung, Penerapan Model Pembelajaran Auditory Intellectually Repetition (AIR) terhadap Hasil Belajar Kognitif Siswa, Jurnal Sainsmat, 2018: 7 (1): 13-24.

[13] Meilan, W., Salastri Rohiat,Hermansyah Amir. Perbandingan Hasil Belajar Siswa Menggunakan Media Call Card Dan Truth And Dare , Alotrop. 2017: 1(1): 39-43.

[14] Medianty, S.U., Amrul Bahar, Elvinawati ,Penerapan Model Discovery Learning Dengan Menggunakan Media Video Untuk Meningkatkan Aktivitas Belajar Dan Hasil Belajar Siswa Kelas XI IPA 1 SMAN 1 Kota Bengkulu , Alotrop, 2018: 2(1): 58-65. [15] Utari ,T.R, Amrul Bahar, Dewi Handayani, Perbandingan Hasil Belajar Siswa Menggunakan Media Daily Chem Quiz Dan Permainan Ranking One Chemistry Quiz, Alotrop ,2017: 1 (2) : 93-97

[16] Oktaviany, N., Penerapan Model Pembelajaran Kooperatif Tipe Rotating Trio Exchange (RTE) Dengan Menggunakan Media Pembelajaran Kartu Arisan Pada Kompetensi Dasar Sambungan Kayu Siswa Kelas X Keterampilan Kayu SMK Negeri 2 Surabaya, Jurnal Kajian Pendidikan Teknik Bangunan , 2017: 2 (2): 197 - 204 
[17] Purnomo, B.H., Metode Dan Teknik Pengumpulan Data Dalam Penelitian Tindakan Kelas (Classroom Action Research), Pengembangan Pendidikan, 2011: 8 (1): 251-256.

[18] Kawi, K.A.Y., I Nengah Suadnyana, IB Surya Manuaba, Pengaruh Model Pembelajaran Auditory, Intellectualy, Repetition Berbantuan Media Audio Visual terhadap Kompetensi Pengetahuan IPA, International Journal of Elementary Education, 2019: 3 (1): 70-78.

[19] Pane, A., Muhammad Darwis Dasopang., Belajar Dan Pembelajaran , FITRAH Jurnal Kajian Ilmu-ilmu Keislaman , 2017: 3 (2): 333-352.

[20] Rohmawati. A., Efektivitas Pembelajaran, Jurnal Pendidikan Usia Dini, 2015: 9(1): 15-32.

[21] Ghofar, A., Fleksibilitas Pengelolaan Kelas Dalam Pendidikan ( Ekspektasi Efektivitas Keberhasilan Proses Pembelajaran) , $A l$ Tarbawi Al-Haditsah: Jurnal Pendidikan Islam , 2017: 2 (1): 24-42

[22] Syahliani, M., M. Arifuddin Jamal, Syubhan An'nur, Penerapan Model Pembelajaran Auditory Intelectually Repetition (AIR) Untuk Meningkatkan Hasil Belajar Siswa, Berkala Ilmiah Pendidikan Fisika , 2014: 2 (3): 213-221.

[23] Ariska,M., Muhammad Fuaddunazmi, Habibi, Pengaruh Pendekatan Pembelajaran AIR (Auditory Intellectually Repetition ) Dengan Metode Demontrasi Terhadap Kemampuan Berkomunikasi Dan Kemampuan Berpikir Kritis Siswa, Jurnal Ilmiah Pendidikan Fisika "Lensa", 2016: 4 (2): 62-65.

[24] Nurmansyah, E., Edy Tandililing, Erwina Oktavianty , Upaya Meningkatkan Hasil Dan Aktivitas Belajar Siswa Melalui Model Auditory Intellectually Repetition (AIR) Pada Materi Energi. Jurnal Pendidikan dan Pembelajaran Khatulistiwa , 2018: 7 (5) :18.

[25] Wibowo, N., Upaya Peningkatan Keaktifan Siswa Melalui Pembelajaran Berdasarkan Gaya Belajar Di SMK Negeri 1 Saptosari, Jurnal Electronics, Informatics, and Vocational Education (ELINVO), 2016: 1(2): 128-139.
Penulisan sitasi artikel ini adalah

Sumiati, D., Amrul Bahar, Dewi Handayani

Penerapan Model Pembelajaran Auditory,

Intellectualy Dan Repetition (AIR) Dengan

Menggunakan Media Pembelajaran Kartu Arisan

Untuk Meningkatkan Aktivitas Dan Hasil Belajar

Siswa Kelas X MIA 1 SMAN 8 Kota Bengkulu, Alotrop , 2018: 3(2): 114-122 